\title{
The Role of CNS Glucagon-Like Peptide-1 (7-36) Amide Receptors in Mediating the Visceral IIIness Effects of Lithium Chloride
}

\author{
Randy J. Seeley, ${ }^{1}$ Kathleen Blake, ${ }^{1}$ Paul A. Rushing, ${ }^{1}$ Stephen Benoit, ${ }^{1}$ John Eng, ${ }^{3}$ Stephen C. Woods, ${ }^{1}$ and \\ David D'Alessio² \\ ${ }^{1}$ Department of Psychiatry and 2Division of Endocrinology, University of Cincinnati College of Medicine, Cincinnati, Ohio \\ 45267-0559, and ${ }^{3}$ Department of Medicine, Bronx VA Medical Center, New York, New York 10468
}

Peripheral administration of large doses of lithium chloride (LiCl) to rats causes a spectrum of effects that are consistent with visceral illness. LiCl reduces food intake, decreases salt ingestion after sodium depletion, induces pica, and produces robust conditioned taste aversions. Because some of the effects of peripheral $\mathrm{LiCl}$ are mimicked by centrally administered glucagon-like peptide-1 (7-36) amide (GLP-1), we hypothesized that this peptide is involved in the neural pathways by which $\mathrm{LiCl}$ causes visceral illness. To test this hypothesis, we pretreated rats with a selective and potent GLP-1 receptor antagonist given directly into the third ventricle via an indwelling cannula before administration of peripheral LiCl. The GLP-1 receptor antagonist completely blocked the effect of $\mathrm{LiCl}$ to reduce food intake, induce pica, and produce a conditioned taste aversion. The same dose of GLP-1 receptor antagonist did not reverse the $\mathrm{LiCl}$-induced reduction in $\mathrm{NaCl}$ intake. The data indicate a role for GLP-1 receptors in the CNS pathway that mediates some of the effects of visceral illness.

Key words: emesis; nucleus of the solitary tract; anorexia; cachexia; food intake; pica; conditioned taste aversion; paraventricular nucleus; central nucleus of the amygdala; nausea
Food intake is influenced by many interacting factors. Some can be considered "homeostatic" in that they participate in the intricate process of matching caloric intake to caloric expenditure and, hence, enable parameters such as blood glucose and body adiposity to stay within rigid limits. The neural systems that mediate these homeostatic factors have received considerable research attention in recent years (Woods et al., 1998). Factors that influence food intake and that are not directly related to energy homeostasis have received far less attention. One such factor is visceral illness (Stricker and Verbalis, 1991). "Visceral illness" is a term that encompasses the nausea and accompanying anorexia that are symptomatic of a wide range of clinical conditions spanning ingestion of toxins, the presence of infections, and the effects of certain tumors or cancers.

The prototypical treatment for eliciting visceral illness in animals is administration of the toxin lithium chloride ( $\mathrm{LiCl})$. Many of the effects of $\mathrm{LiCl}$ are consistent with the presence of visceral illness. For example, $\mathrm{LiCl}$ administration elicits vomiting in species that have emetic reflexes (e.g., dogs, ferrets, and primates) as well as subjective feelings of nausea in humans. Accompanying the nausea is a reduction of food intake, and this occurs in species that do not vomit, such as rats (McCann et al., 1989). However, because reductions of food intake in rats could be a result of homeostatic and/or nonhomeostatic influences, anorexia by itself is not a reliable indicator of the presence of visceral illness in these species. The anorexia associated with $\mathrm{LiCl}$ is not limited to the intake of calories. Treatments that deplete body sodium cause

Received Aug. 23, 1999; revised Nov. 15, 1999; accepted Dec. 3, 1999.

This work was supported by National Institutes of Health (Grants DK54890, DK54080, DK17844), the American Diabetes Association, and funds from the Procter \& Gamble Company.

Correspondence should be addressed to Dr. Randy J. Seeley, Department of Psychiatry, University of Cincinnati College of Medicine, Box 670559, Cincinnati, OH 45267-0559. E-mail: seeleyrj@email.uc.edu.

Copyright (C) 2000 Society for Neuroscience $\quad 0270-6474 / 00 / 201616-06 \$ 15.00 / 0$ most animals to exhibit a specific and robust appetite for sodiumcontaining solutions (Stricker and Verbalis, 1990), and administration of $\mathrm{LiCl}$ or other toxins produces a significant reduction in this sodium appetite (Stricker and Verbalis, 1990, 1996; Chavez et al., 1995). This suggests that the illness response elicited by $\mathrm{LiCl}$ affects more than one motivational system. When administered after rats have sampled a novel taste, $\mathrm{LiCl}$ causes rats to avoid that taste in the future [i.e., to form a conditioned taste aversion (Garcia et al., 1974)]. Finally, LiCl or other toxins elicit increased consumption of a pharmaceutical grade clay (kaolin) (Mitchell et al., 1977a,b; Madden et al., 1999), a behavior only observed when animals are thought to be ill. Thus, $\mathrm{LiCl}$ induces a constellation of specific symptoms and behaviors in rats that have been used as indications of visceral illness.

We have noted previously that several of the responses indicative of visceral illness in rats also were caused by the central administration of the brain-gut peptide glucagon-like peptide-1 (GLP-1). GLP-1 potently reduces food intake (Tang-Christensen et al., 1996; Turton et al., 1996; van Dijk et al., 1996; Thiele et al., 1997) and, like $\mathrm{LiCl}$, also elicits a conditioned taste aversion (Thiele et al., 1997; van Dijk et al., 1997). Because GLP-1 is synthesized by a distinct subpopulation of neurons in the hindbrain (Han et al., 1986) as well as in the distal intestine, we hypothesized that this peptide was involved in the neural pathways activated by $\mathrm{LiCl}$ during the visceral illness response. In support of this hypothesis we recently reported that central administration of a selective GLP-1 receptor antagonist greatly attenuates the increase in fos-like immunoreactivity in the area postrema, nucleus tractus solitarii (NTS), and parabrachial nucleus, induced by the administration of $\mathrm{LiCl}$ (Thiele et al., 1998). To test this hypothesis fully, we have assessed the effect of central GLP-1 receptors in the mediation of the broad spectrum of visceral illness responses induced by $\mathrm{LiCl}$ in rats. 


\section{MATERIALS AND METHODS}

Experiment 1: Food intake and GLP-1. Eighteen male Long-Evans rats (275-350 gm) obtained from Harlan Labs (Indianapolis, IN) were housed individually in plastic "tub" cages with a $12 \mathrm{hr}$ light/dark cycle. All rats were implanted stereotaxically with third ventricular cannulas (for details of this procedure, see Seeley et al., 1996). Cannula placement was verified by administering angiotensin II $(10 \mathrm{nmol} / 1 \mu \mathrm{l})$ through the cannula (i3vt). Rats that failed to drink at least $5 \mathrm{ml}$ of water in the 60 min after angiotensin II treatment were removed from the study. Rats were divided into three weight-matched groups ( $n=6 /$ group): saline/ saline, saline/GLP-1, and exendin/GLP-1. Food was removed from each animal's cage $2.5 \mathrm{hr}$ before lights off. At $1 \mathrm{hr}$ before lights off the rats received an i3vt injection of either saline or des-His ${ }_{1}$, Glu ${ }_{9}$-exendin-4 [10 $\mu \mathrm{g} / 2 \mu \mathrm{l}$; American Peptides, Sunnyvale, CA (Montrose-Rafizadeh et al., 1997)]. Then $15 \mathrm{~min}$ later the rats received a second i3vt injection of either saline or GLP-1 (7-36) amide (10 $\mu \mathrm{g} / 2 \mu \mathrm{l}$; American Peptides). Food was replaced at lights off, and intake was measured hourly for $4 \mathrm{hr}$ and then again at $24 \mathrm{hr}$.

Experiment 2: Food intake and $\mathrm{LiCl}$. Thirty-two naïve male LongEvans rats (400-500 gm at the time of the experiment) were housed and cannulated as described above. Rats were assigned to four weightmatched groups: saline/saline $(n=8)$, exendin/saline $(n=8)$, saline/ $\mathrm{LiCl}(n=8)$, or exendin/ $\mathrm{LiCl}(n=8)$. Food was removed from each animal's cage $2.5 \mathrm{hr}$ before lights off. At $1 \mathrm{hr}$ before lights off the rats received an i3vt injection of either saline or des-His ${ }_{1}$, Glu ${ }_{9}$-exendin-4 (50 $\mu \mathrm{g} / 5 \mu \mathrm{l})$. Then $15 \mathrm{~min}$ later they received an intraperitoneal injection of $0.15 \mathrm{M}$ saline or $0.15 \mathrm{M} \mathrm{LiCl}$ at a volume equivalent to $2 \%$ of their body weight. Food was replaced at lights off, and intake was measured every 30 $\min$ for $2 \mathrm{hr}$.

Experiment 3: Conditioned taste aversion. Male Long-Evan rats (250$350 \mathrm{gm}$ ) obtained from Charles River (Wilmington, MA) were housed identically to those in Experiment 1 . Rats received i3vt cannulas and a surgically implanted intraoral catheter made of polyethylene 100 tubing with a Teflon washer at one end. The intraoral catheter passed subcutaneously from just lateral to the first maxillary molar to the rear of the skull and allowed infusion of taste stimuli directly into the oral cavity. Then the rat could either consume or reject the solution. All rats were habituated to a Plexiglas observation chamber for $20 \mathrm{~min} / \mathrm{d}$ for $4 \mathrm{~d}$. On the last $2 \mathrm{~d}$ of habituation the rats received an intraoral infusion of $5 \mathrm{ml}$ of distilled water $(0.5 \mathrm{ml} / \mathrm{min})$ during the last $10 \mathrm{~min}$ in the chamber. On the conditioning day the rats received an i3vt injection of either saline or des-His $_{1}$, Glu $_{9}$-exendin-4 $(50 \mu \mathrm{g} / 5 \mu \mathrm{l})$ and then were placed in the observation chamber. After $9 \mathrm{~min}$ they were infused with $2.5 \mathrm{ml}$ of a $0.5 \%$ aqueous saccharine solution via the intraoral catheter at a rate of $0.5 \mathrm{ml} / \mathrm{min}$. Then $1 \mathrm{~min}$ after the infusion ended, the rats were given an intraperitoneal injection of either $0.15 \mathrm{~m}$ saline or $0.15 \mathrm{M} \mathrm{LiCl}(2 \%$ of body weight) and returned to their home cages. The rats were tested 48 $\mathrm{hr}$ later by being given an intraoral infusion of the saccharine solution $(2.5 \mathrm{ml}$ over $5 \mathrm{~min})$. The amount of time that elapsed before the rat rejected the flavor was recorded by an observer who was blind to the experimental condition. This procedure has been used reliably as a sensitive marker of the presence of a conditioned taste aversion (Houpt et al., 1994; Thiele et al., 1997; van Dijk et al., 1997).

Experiment 4: Kaolin intake. Thirty male Long-Evans rats (300-400 gm) from Charles River were housed individually in mesh-bottomed stainless steel cages on a $12 \mathrm{hr}$ light/dark cycle. All rats were implanted with i3vt cannulas as described above. Rats were habituated to having access to dry kaolin pellets for $10 \mathrm{~d}$ before testing. Kaolin consists of kaolin powder (Sigma, St. Louis, MO) and 1\% acacia gum mixed with water. The paste is converted into $1 \mathrm{~cm}$ in diameter cylinders by being squeezed through a pastry decorator onto Plexiglas sheets and allowed to dry for several days. The hard kaolin is then broken into pellets and put into a food hopper. Rats were assigned to four weight-matched groups: saline/saline $(n=7)$, exendin/saline $(n=8)$, saline/LiCl $(n=7)$, or exendin/ $\mathrm{LiCl}(n=8)$. Rats received an i3vt injection of either saline or des-His ${ }_{1}, \mathrm{Glu}_{9}$-exendin-4 (50 $\left.\mu \mathrm{g} / 5 \mu \mathrm{l}\right) 3.5 \mathrm{hr}$ after lights on. Then $15 \mathrm{~min}$ after the i3vt injection the rats received an intraperitoneal injection of either $0.15 \mathrm{~m}$ saline or $0.15 \mathrm{~m} \mathrm{LiCl}$ ( $2 \%$ of body weight). Immediately after the intraperitoneal injection the kaolin was weighed and replaced in the animal's home cage. Kaolin intake was measured after 1, 2, and $24 \mathrm{hr}$. Then $7 \mathrm{~d}$ later the experiment was repeated, with rats in the saline/saline group switched with rats in the saline/ $\mathrm{LiCl}$ condition, and rats in the exendin/saline condition were switched with rats in the exendin/ $\mathrm{LiCl}$ condition.

Experiment 5: $\mathrm{NaCl}$ intake. Thirty male Long-Evan rats (300-400 gm) obtained from Harlan were housed individually with a $12 \mathrm{hr}$ light/dark cycle. All rats were implanted with i3vt cannulas as described above. Rats had access to a $0.5 \mathrm{~m}$ saline solution for $10 \mathrm{~d}$ before testing. Tap water was available ad libitum. On the first day of the experiment, $3.5 \mathrm{hr}$ before lights off, chow and $0.5 \mathrm{~m}$ saline were removed from the cage. Then 30 min later the animals received an injection of furosemide $(100 \mathrm{mg} / 10 \mathrm{ml})$ at a dose of $5 \mathrm{mg} / \mathrm{kg}$ subcutaneously. The animals received a second, identical injection of furosemide $1 \mathrm{hr}$ later. Sodium-free chow (ICN Biomedicals, Aurora, $\mathrm{OH}$ ) was placed in the animals' cages.

On the second day of the experiment the rats were assigned to one of four weight-matched groups: saline/saline $(n=7)$, exendin/saline $(n=$ $7)$, saline/LiCl $(n=8)$, or exendin/LiCl $(n=9)$. Four and one-half $\mathrm{hr}$ before lights off, the animals received an i3vt injection of des-His ${ }_{1}$, $\mathrm{Glu}_{9}$-exendin-4 $(50 \mu \mathrm{g} / 5 \mu \mathrm{l})$ or saline. Then $15 \mathrm{~min}$ after the i3vt injection the rats received an intraperitoneal injection of either $0.15 \mathrm{M}$ saline or $0.15 \mathrm{M} \mathrm{LiCl}$ ( $2 \%$ of body weight). Immediately after the intraperitoneal injection the $0.5 \mathrm{M}$ saline solution was replaced on the animal's cage, and intake was measured after 30, 60, 90, and 120 min.

\section{RESULTS}

With the exception of Experiment 1 in which the effects of GLP-1 were compared with the other two groups by using Student's $t$ tests, the data were analyzed with a two-way ANOVA, with one factor being $\mathrm{LiCl}$ condition (intraperitoneal $\mathrm{LiCl}$ vs intraperitoneal saline) and the other factor being exendin condition (i3vt exendin vs i3vt saline). Post hoc analyses used the Least Significant Difference (LSD) test with significance set at $p \leq 0.05$. In Experiment 4 the exendin condition was run within subjects, so a mixed model ANOVA was used for the data analysis.

\section{Experiment 1: Food intake and GLP-1}

Exogenous administration of $10 \mu \mathrm{g}$ of GLP-1 i3vt significantly reduced food intake over the first $4 \mathrm{hr}$ of the dark cycle. Pretreatment with $10 \mu \mathrm{g}$ of exendin i3vt completely blocked this effect of exogenous GLP-1 (Fig. 1, Top). Rats in the saline/GLP-1 group ate significantly less than both the saline/saline group $\left(t_{(10)}=\right.$ $2.34 ; p=0.04)$ and the exendin/GLP-1 group $\left(t_{(10)}=2.32 ; p=\right.$ $0.04)$. This experiment demonstrates the potent effectiveness of des-His $_{1}$, Glu $_{9}$-exendin-4 to act as an antagonist for exogenously administered GLP-1.

\section{Experiment 2: Food intake and $\mathrm{LiCl}$}

In Experiment 2, at 30 min there was a significant main effect for exendin $\left(F_{(1,29)}=4.13 ; p=0.05\right)$, but not for $\operatorname{LiCl}\left(F_{(1,29)}=1.01\right.$; $p=0.32)$ nor for the interaction $\left(F_{(1,29)}=0.53 ; p=0.43\right)$. Post hoc analyses with the LSD test showed that $\mathrm{LiCl}$ inhibited food intake over the first $30 \mathrm{~min}$ of the dark cycle but had no reliable effect on cumulative food intake over a $2 \mathrm{hr}$ period (data not shown). Pretreatment with $50 \mu \mathrm{g}$ of exendin i3vt completely blocked the effect of $\mathrm{LiCl}$ to inhibit food intake over $30 \mathrm{~min}$. At $30 \mathrm{~min}$ the intake of the saline/ $\mathrm{LiCl}$ group was significantly less than all three other groups in the experiment (Fig. 1, Bottom).

\section{Experiment 3: Conditioned taste aversion}

In Experiment 3 there was a significant main effect for exendin $\left(F_{(1,11)}=4.95 ; p=0.04\right), \operatorname{LiCl}\left(F_{(1,11)}=14.48 ; p=0.002\right)$, and their interaction $\left(F_{(1,11)}=10.98 ; p=0.006\right)$. On reexposure to the saccharine solution the rats that had received $\mathrm{LiCl}$ paired with the saccharin on a previous day consumed significantly less of the saccharine solution. Pretreatment with $50 \mu \mathrm{g}$ of exendin i3vt on the training day completely blocked the effect of $\mathrm{LiCl}$ to elicit a conditioned taste aversion as assessed by the reduced consumption of the saccharine solution on the test day (Fig. 2). Post hoc analyses that used the LSD test showed that the saline/ $\mathrm{LiCl}$ group consumed significantly less saccharine solution than the other three groups $(p<0.002)$. 

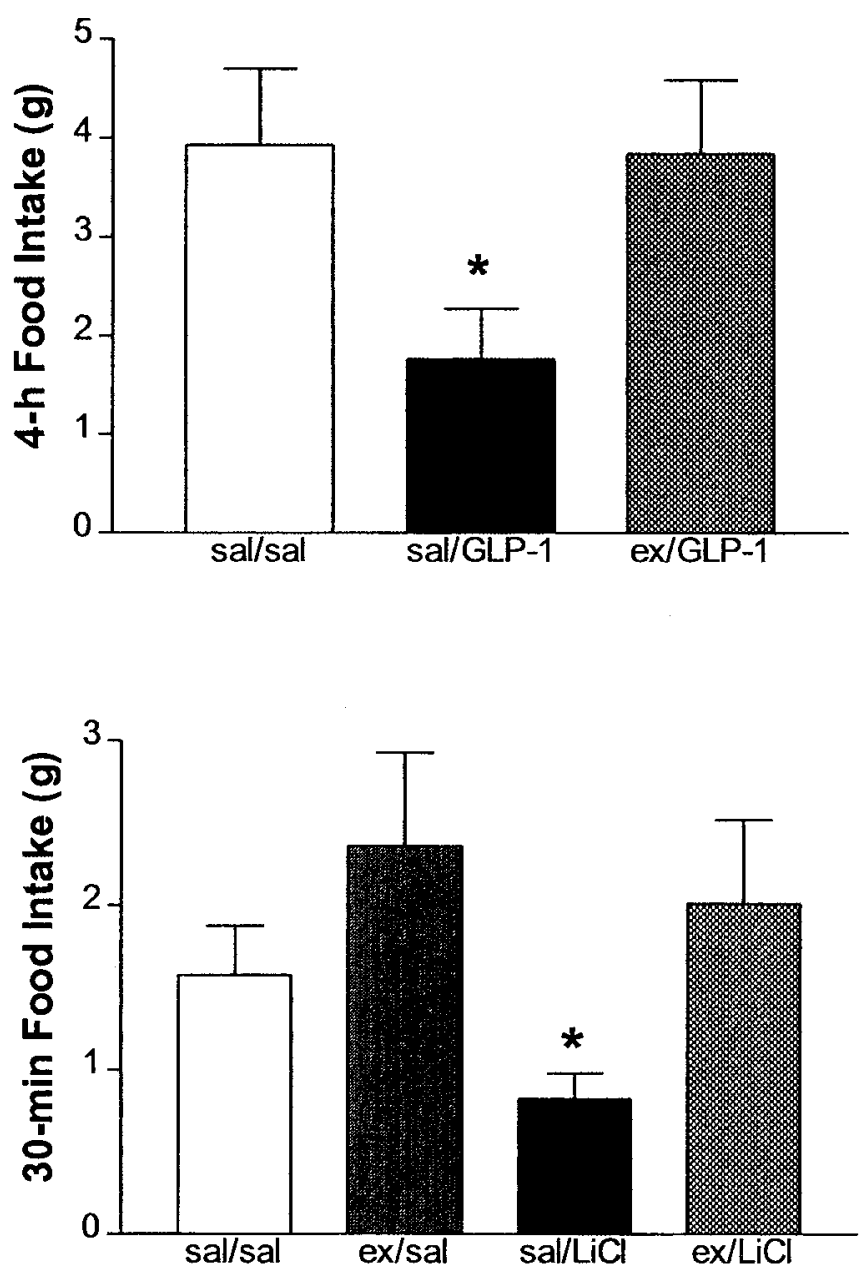

Figure 1. Top, Cumulative $4 \mathrm{hr}$ food intake (mean \pm SEM) after i3vt administration of GLP-1 (10 $\mu \mathrm{g})$ or GLP-1 after pretreatment with the GLP-1 receptor antagonist des-His ${ }_{1}$, Glu ${ }_{9}$-exendin-4 $(10 \mu \mathrm{g})$. *Significantly different from both other groups at $p<0.05$. Bottom, Cumulative $30 \mathrm{~min}$ food intake (mean \pm SEM) after i3vt administration of either saline or exendin $(50 \mu \mathrm{g})$, followed by an intraperitoneal injection of either isotonic saline or $\mathrm{LiCl}$. *Significantly different from all other groups at $p<0.05$.

\section{Experiment 4: Kaolin intake}

In Experiment 4 there was a significant effect of $\operatorname{LiCl}\left(F_{(1,13)}=\right.$ $4.45 ; p=0.05)$ but not quite significant for exendin $\left(F_{(1,13)}=1.74\right.$; $p=0.08)$, but the interaction was significant $\left(F_{(1,13)}=4.45 ; p=\right.$ 0.05). Post hoc analyses with the use of Tukey's HSD reveals that the saline/ $\mathrm{LiCl}$ group consumed significantly more kaolin than the three other groups after $1 \mathrm{hr}$ (Fig. 3, Top).

\section{Experiment 5: $\mathrm{NaCl}$ intake}

In Experiment 5 there was a significant effect of $\operatorname{LiCl}\left(F_{(1,26)}=\right.$ 28.86; $p<0.0001)$, but no effect of exendin $\left(F_{(1,26)}=1.39 ; p=\right.$ $0.25)$ nor a significant interaction $\left(F_{(1,26)}=2.43 ; p=0.14\right)$. LiCl decreased consumption of a hypertonic $\mathrm{NaCl}$ solution over the 2 hr period in rats that were treated with a diuretic and that were exposed to $\mathrm{Na}^{+}$-deficient chow. Unlike the other effects of $\mathrm{LiCl}$ assessed in these experiments, pretreatment with $50 \mu \mathrm{g}$ of exendin i3vt did not alter this effect of LiCl (Fig. 3, Bottom). Both the saline/ $\mathrm{LiCl}$ and the exendin/ $\mathrm{LiCl}$ groups consumed significantly less hypertonic $\mathrm{NaCl}$ than the saline/saline and exendin/ saline groups. Moreover, the saline $/ \mathrm{LiCl}$ and exendin $/ \mathrm{LiCl}$

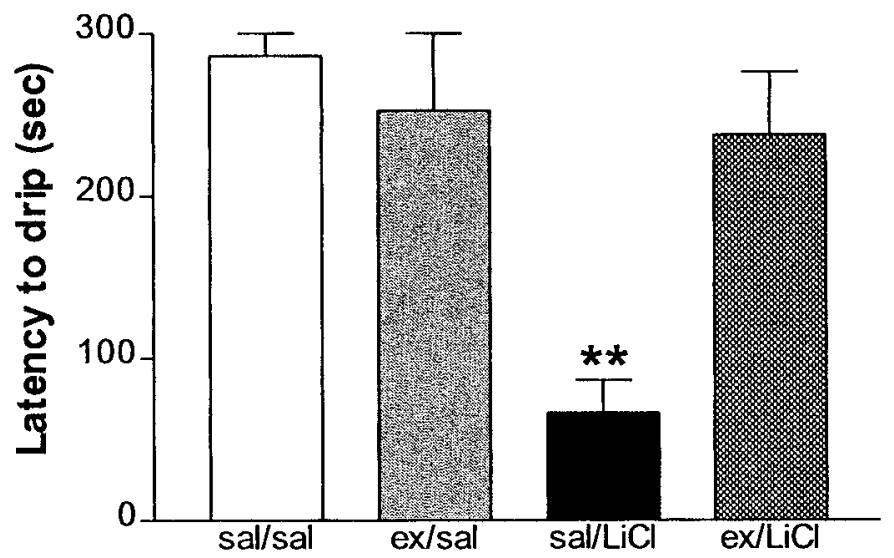

Figure 2. Latency (mean \pm SEM) to reject a saccharin solution being infused via an intraoral catheter on the test day. Rats previously had had the saccharin solution paired with either an intraperitoneal injection of saline or $\mathrm{LiCl}$ that was preceded by a i3vt injection of either saline or exendin. **Significantly different from all other groups at $p<0.01$.

groups did not differ from one another at any time point. The exendin used in these experiments was prepared identically from the same batch as the previous experiments in which exendin exerted a significant effect. Additionally, the exendin was made fresh for each of the two experimental test days, and the pattern of data is identical on the two experimental test days.

\section{DISCUSSION}

$\mathrm{LiCl}$ produces a spectrum of results that are consistent with the production of visceral illness. In humans, $\mathrm{LiCl}$ produces emesis and reports of nausea (Stricker and Verbalis, 1991). The present results replicate and extend previous reports that peripheral administration of $\mathrm{LiCl}$ reduces short-term food intake (McCann et al., 1989; Wolgin and Wade, 1990), elicits conditioned taste aversions (McCann et al., 1989; Wolgin and Wade, 1990), increases intake of non-nutritive clay (kaolin) (Mitchell et al., 1976), and decreases $\mathrm{NaCl}$ intake after diuretic treatment (Chavez et al., 1995).

Several reports indicate that i3vt administration of GLP-1 produces effects that resemble those of peripherally administered LiCl. I3vt GLP-1 suppresses food intake and produces conditioned taste aversions (Thiele et al., 1997; van Dijk et al., 1997). Like LiCl, GLP-1 reduces body temperature, decreases locomotor activity, and decreases gastric emptying (O'Shea et al., 1996; Williams et al., 1996; Wettergren et al., 1997). I3vt GLP-1 also produces a pattern of increased fos-like immunoreactivity in the hindbrain similar to that produced by LiCl (van Dijk et al., 1996; Rowland et al., 1997). Specifically, both increase fos activity in the area postrema, nucleus of the solitary tract, and parabrachial nucleus as well as in the paraventricular nucleus of the hypothalamus and the central nucleus of the amygdala (Houpt et al., 1994; Thiele et al., 1996; Turton et al., 1996; van Dijk et al., 1996). Given these similarities, we hypothesized that increased signaling via CNS GLP-1 receptors is an important part of the cascade of events that mediate the effects of $\mathrm{LiCl}$. Consistent with this hypothesis, pretreatment with a GLP-1 receptor antagonist significantly attenuated the LiCl-induced fos-like immunoreactivity in the area postrema, nucleus of the solitary tract, and parabrachial nucleus (Thiele et al., 1998).

The relationship between this change in fos expression and the behavioral effects of $\mathrm{LiCl}$ cannot be determined a priori. Conse- 

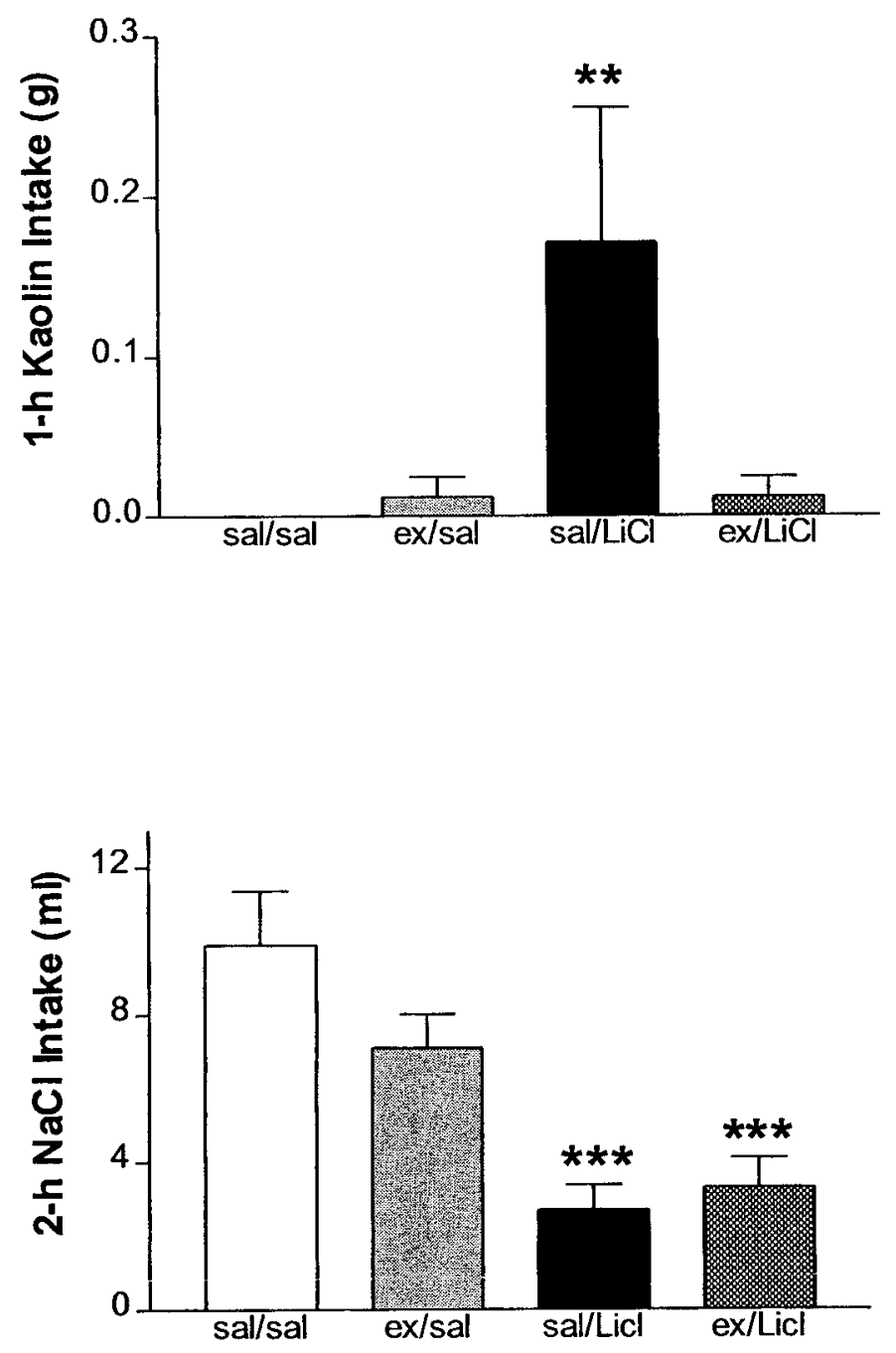

Figure 3. Top, Cumulative $1 \mathrm{hr}$ kaolin (clay) consumption (mean \pm SEM). Rats received an intraperitoneal injection of isotonic saline or $\mathrm{LiCl}$ ( $2 \%$ of body weight). Saline or $\mathrm{LiCl}$ injection was preceded by either i3vt saline or exendin $(50 \mu \mathrm{g})$. **Significantly different from all other groups at $p \leq 0.01$. Bottom, Cumulative $2 \mathrm{hr}$ intake (mean $\pm \mathrm{SEM}$ ) of 0.5 $\mathrm{M} \mathrm{NaCl}$ solution after diuretic treatment and exposure to $\mathrm{Na}^{+}$-deficient chow. Rats received an intraperitoneal injection of isotonic saline or $\mathrm{LiCl}$ ( $2 \%$ of body weight). Saline or $\mathrm{LiCl}$ injection was preceded by either i3vt saline or exendin $(50 \mu \mathrm{g}) . * *$ Significantly different from saline/saline and exendin/saline groups at $p<0.001$.

quently, the current experiments sought to determine the effect of GLP-1 receptor blockade on several behavioral effects of $\mathrm{LiCl}$. The GLP-1 receptor antagonist used in these experiments (desHis $_{1}$ Glu $_{9}$-exendin-4; $10 \mu \mathrm{g}$ ) completely blocked the anorexic response to a $10 \mu \mathrm{g}$ dose of exogenous i3vt GLP-1. The present data are therefore consistent with data from cell lines expressing

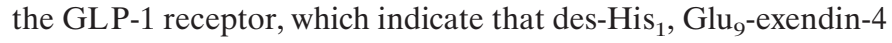
is 10-100 times more potent than the more commonly used GLP-1 receptor antagonist, exendin-9-39 (Goke et al., 1995; Turton et al., 1996; Montrose-Rafizadeh et al., 1997; Thiele et al., 1998).

Very similar to recent data from Rinaman (1999a), pretreatment with the GLP-1 receptor antagonist completely blocked the ability of $\mathrm{LiCl}$ to reduce food intake. There was a nonsignificant trend toward exendin alone increasing food intake. Hence it might be argued that the effect of exendin has little to do with a specific interaction with LiCl-induced effects. However, it seems very unlikely that independent actions of exendin can account for the range of effects we noted in this study. The conditioned taste aversion and increased kaolin consumption induced by $\mathrm{LiCl}$ were blocked completely by the GLP-1 receptor antagonist, which had no effect by itself on these dependent variables. Hence the data collectively argue for an important interaction between the $\mathrm{LiCl}$ treatment and the GLP-1 receptor antagonist. Although alternative explanations might be offered for any one of these three measures, the consistency of the data across all three measures argues strongly that some aspect of the visceral illness response to $\mathrm{LiCl}$ depends critically on increased activity at CNS GLP-1 receptors.

Interestingly, although the data for food intake, conditioned taste aversion, and kaolin are consistent with an important effect of signaling via the GLP-1 receptor to produce these symptoms of visceral illness, the data from the sodium appetite test are not. The GLP-1 receptor antagonist did not alter hypertonic $\mathrm{NaCl}$ intake by itself, nor did it reverse the LiCl-induced reduction at the same dose that was effective with the other three measures. There are at least two possibilities for this dissociation between $\mathrm{NaCl}$ intake and the other behavioral effects of LiCl. First, LiCl-induced reductions in sodium appetite may depend on a different population of GLP-1 receptors than the effects on food intake, conditioned taste aversion, and kaolin consumption. In addition to several brainstem regions and the paraventricular nucleus of the hypothalamus, GLP-1 receptors are located in the central nucleus of the amygdala (Goke et al., 1995). LiCl increases fos-like immunoreactivity in the central nucleus of the amygdala (Houpt et al., 1994; Swank et al., 1994; van Dijk et al., 1996), and several lines of evidence point to an important role for this structure in the control of $\mathrm{NaCl}$ intake (Galaverna et al., 1993; Seeley et al., 1993; Johnson and Thunhorst, 1997). Given that the amygdala is quite lateral to the third ventricle, it is possible that i3vt administration of the antagonist may block the hypothalamic and brainstem populations of GLP-1 receptors while not reaching the critical receptors for mediating the effects on $\mathrm{Na}^{+}$appetite in the amygdala.

The second possibility is that the GLP-1 system is not critical to the effects of $\mathrm{LiCl}$ on $\mathrm{NaCl}$ intake. Rather, some other neurochemical system may mediate the $\mathrm{NaCl}$ intake effect. At least one good candidate for that system is the CNS oxytocin system. Plasma oxytocin levels are elevated dramatically in rats treated with $\mathrm{LiCl}$ (McCann et al., 1989), and central administration of oxytocin reduces $\mathrm{NaCl}$ intake (Stricker and Verbalis, 1996). Hence, it may be that $\mathrm{LiCl}$ engages several central neurochemical systems in parallel, with each mediating different subsets of these effects.

The present results provide compelling evidence that the endogenous GLP-1 system mediates some of the effects of $\mathrm{LiCl}$. Several questions, however, remain to be answered. First, the source of the endogenous GLP-1 blocked by the antagonist is not clear. In addition to being made in a discrete population of neurons in the brainstem, GLP-1 also is made in the distal small intestine where it is released into the general circulation. Plasma levels of GLP-1 can be quite substantial, and there is evidence that circulating GLP-1 enters the CNS, at least in areas with a reduced blood-brain barrier (Hassan et al., 1999). Hence, it is possible that intraperitoneally administered $\mathrm{LiCl}$ acts peripherally to increase circulating GLP-1 levels that eventually act on CNS GLP-1 receptors. We think that this possibility is less likely, 
given that intraperitoneal administration of GLP-1 in rats does not reduce food intake (Tang-Christensen et al., 1996; Turton et al., 1996). The hypothesis that the endogenous source of the GLP-1 is in the CNS is supported by the increased fos-like immunoreactivity (and hence increased neuronal activity) observed in GLP-1 neurons after LiCl treatment (Rinaman, 1999b). Direct measurement of GLP-1 levels in the periphery and gene expression for the precursor to GLP-1 in the brainstem should be able to address this issue.

A second question raised by the present results concerns the population of GLP-1 receptors that mediate the effects of LiCl. GLP-1 receptors are found in both forebrain and hindbrain areas that have been identified as important in the regulation of food intake and the formation of conditioned taste aversions. Hence, it is possible that either population of receptors contributes to some or all of the LiCl-mediated effects. Comparison of third ventricular to fourth ventricular administration of the antagonist or alternatively site-specific injection of the antagonist potentially could identify the critical receptor populations for the various effects (for an example of this strategy, see Grill et al., 1998).

Many CNS systems contribute to the homeostatic regulation of food intake and body adiposity. In addition, a number of important influences on food intake and behavior are best categorized as nonhomeostatic. One such influence is the presence of visceral illness. The present results suggest that several key consequences of visceral illness elicited by $\mathrm{LiCl}$ are mediated by the endogenous GLP-1 system acting in the CNS, including effects on food intake. Hence it would appear that one major role of the CNS GLP-1 system is to mediate some of the nonhomeostatic influences on ingestive behavior. It is important to note that this conclusion does not rule out GLP-1 as also being involved in homeostatic controls over food intake. When GLP-1 is administered directly into the paraventricular nucleus of the hypothalamus, food intake is reduced and there is no concomitant development of a conditioned taste aversion (McMahon and Wellman, 1997). Additionally, GLP-1 receptor antagonists can increase food intake without any obvious presence of visceral illness (Turton et al., 1996; Goldstone et al., 1997). Consequently, GLP-1 signaling in the brain may be involved with both homeostatic and nonhomeostatic influences on ingestive behavior and may, in fact, integrate these two sets of regulatory controls on food intake.

\section{REFERENCES}

Chavez M, Seeley RJ, Woods SC (1995) A comparison between the effects of intraventricular insulin and intraperitoneal $\mathrm{LiCl}$ on three measures sensitive to emetic agents. Behav Neurosci 109:547-550.

Galaverna OG, Seeley RJ, Berridge KC, Grill HJ, Epstein AN, Schulkin J (1993) Lesions of the central nucleus of the amygdala. I. Effects on taste reactivity, taste aversion learning, and sodium appetite. Behav Brain Res 59:11-17.

Garcia J, Hankins WG, Rusiniak KW (1974) Behavioral regulation of the milieu interne in man and rat. Science 185:267-269.

Goke R, Larsen PJ, Mikkelsen JD, Skeikh SP (1995) Distribution of GLP-1 binding sites in the rat brain: evidence that exendin is a ligand of brain GLP-1 sites. Eur J Neurosci 7:2294-2300.

Goldstone AP, Mercer JG, Gunn I, Moar KM, Edwards CM, Rossi M, Howard JK, Rasheed S, Turton MD, Small C, Heath MM, O'Shea D, Steere J, Meeran K, Ghatei MA, Hoggard N, Bloom SR (1997) Leptin interacts with glucagon-like peptide-1 neurons to reduce food intake and body weight in rodents. FEBS Lett 415:134-138.

Grill HJ, Ginsberg AB, Seeley RJ, Kaplan JM (1998) Brainstem application of melanocortin receptor ligands produces long-lasting effects on feeding and body weight. J Neurosci 18:10128-10135.
Han VKM, Hynes MA, Jin C, Towle AC, Lauder JM, Lund PK (1986) Cellular localization of proglucagon/glucagon-like peptide 1 messenger RNAs in rat brain. J Neurosci Res 16:97-107.

Hassan M, Eskilsson A, Nilsson C, Jonsson C, Jacobsson H, Refai E, Larsson S, Efendic S (1999) In vivo dynamic distribution of 131Iglucagon-like peptide-1 (7-36) amide in the rat studied by gamma camera. Nucl Med Biol 26:413-420.

Houpt TA, Philopena JM, Wessel TC, Joh TH, Smith GP (1994) Increased c-fos expression in nucleus of the solitary tract correlated with conditioned taste aversion to sucrose in rats. Neurosci Lett 172:1-5.

Johnson AK, Thunhorst RL (1997) The neuroendocrinology of thirst and sodium appetite: visceral sensory signals and mechanisms of central integration. Front Neuroendocrinol 18:292-353.

Madden LJ, Seeley RJ, Woods SC (1999) Intraventricular neuropeptide $\mathrm{Y}$ decreases need-induced sodium appetite and increases pica in rats. Behav Neurosci 113:826-832.

McCann MJ, Verbalis JG, Stricker EM (1989) LiCl and CCK inhibit gastric emptying and feeding and stimulate OT secretion in rats. Am J Physiol 256:R463-R468.

McMahon LR, Wellman PJ (1997) PVN infusion of GLP-1 (7-36) amide suppresses feeding and drinking but does not induce conditioned taste aversions or alter locomotion in rats. Am J Physiol 274:R23-R29.

Mitchell D, Wells C, Hoch N, Lind K, Woods SC, Mitchell LK (1976) Poison-induced pica in rats. Physiol Behav 17:691-697.

Mitchell D, Krusemark ML, Hafner E (1977a) Pica: a species-relevant behavioral assay of motion sickness in rats. Physiol Behav 18:125-130.

Mitchell D, Winter W, Morisaki CM (1977b) Conditioned taste aversions accompanied by geophagia: evidence for the occurrence of "psychological" factors in the etiology of pica. Psychosom Med 39:401-412.

Montrose-Rafizadeh C, Yang H, Rodgers BD, Beday A, Pritchette LA, Eng J (1997) High potency antagonists of the pancreatic glucagon-like peptide-1 receptor. J Biol Chem 272:21201-21206.

O'Shea D, Gunn I, Chen X, Bloom S, Herbert J (1996) A role for central glucagon-like peptide-1 in temperature regulation. NeuroReport 7:830-832.

Rinaman L (1999a) A functional role for central glucagon-like peptide-1 receptors in lithium chloride-induced anorexia. Am J Physiol 277:R1537-R1540.

Rinaman L (1999b) Interoceptive stress activates glucagon-like peptide-1 neurons that project to the hypothalamus. Am J Physiol 277:R582-R590.

Rowland NE, Crews EC, Gentry RM (1997) Comparison of fos induced in rat brain by GLP-1 and amylin. Regul Pept 71:171-174.

Seeley RJ, Galaverna OG, Schulkin J, Epstein AN, Grill HJ (1993) Lesions of the central nucleus of the amygdala. II. Effects on intraoral $\mathrm{NaCl}$ intake. Behav Brain Res 59:19-25.

Seeley RJ, van Dijk G, Campfield LA, Smith FJ, Nelligan JA, Bell SM, Baskin DG, Woods SC, Schwartz MW (1996) The effect of intraventricular administration of leptin on food intake and body weight in the rat. Horm Metab Res 28:664-668.

Stricker EM, Verbalis JG (1990) Sodium appetite. In: Handbook of behavioral neurobiology: neurobiology of food and fluid intake (Stricker EM, ed), pp 45-60. New York: Plenum.

Stricker EM, Verbalis JG (1991) Caloric and noncaloric controls of food intake. Brain Res Bull 27:299-303.

Stricker EM, Verbalis JG (1996) Central inhibition of salt appetite by oxytocin in rats. Regul Pept 66:83-85.

Swank MW, Schafe GE, Bernstein IL (1994) c-Fos induction in response to taste stimuli previously paired with amphetamine or $\mathrm{LiCl}$ during taste aversion learning. Brain Res 673:251-261.

Tang-Christensen M, Larsen PJ, Goke R, Fink-Jensen A, Jessop DS, Moller M, Sheikh SP (1996) Central administration of GLP-1 (7-36) amide inhibits food and water intake in rats. Am J Physiol 271:R848-R856.

Thiele TE, Roitman MF, Bernstein IL (1996) c-Fos induction in rat brainstem in response to ethanol- and lithium chloride-induced conditioned taste aversions. Alcohol Clin Exp Res 20:1023-1028.

Thiele TE, van Dijk G, Campfield LA, Smith FJ, Burn P, Woods SC, Bernstein IL, Seeley RJ (1997) Central administration of GLP-1, but not leptin, produces conditioned taste aversions in the rat. Am J Physiol 272:R726-R730.

Thiele TE, Seeley RJ, D'Alessio D, Eng J, Woods SC, Bernstein IL (1998) Central infusion of GLP-1 (7-36) amide receptor antagonist attenuates lithium chloride-induced c-Fos induction in rat brainstem. Brain Res 801:164-170. 
Turton MD, O'Shea D, Gunn I, Beak SA, Edwards CMB, Meeran K, Choi SJ, Taylor GM, Heath MM, Lambert PD, Wilding JPH, Smith DM, Ghatei MA, Herbert J, Bloom SR (1996) A role for glucagonlike peptide-1 in the central regulation of feeding. Nature 379:69-72. van Dijk G, Thiele TE, Donahey JCK, Campfield LA, Smith FJ, Burn P, Bernstein IL, Woods SC, Seeley RJ (1996) Central infusion of leptin and GLP-1 (7-36) amide differentially stimulate c-Fos-like immunoreactivity in the rat brain. Am J Physiol 271:R1096-R1100.

van Dijk G, Thiele TE, Seeley RJ, Woods SC, Bernstein IL (1997) Glucagon-like peptide-1 and satiety. Nature 385:214.

Wettergren A, Wojdemann M, Meisner S, Stadil F, Holst JJ (1997) The inhibitory effect of glucagon-like peptide-1 (GLP-1) 7-36 amide on gastric acid secretion in humans depends on an intact vagal innervation. Gut 40:597-601.

Williams B, Werner J, Holst JJ, Orskov C, Creutzfeldt W, Nauck MA (1996) Gastric emptying, glucose responses, and insulin secretion after a liquid test meal: effects of exogenous glucagon-like peptide 1 (GLP-1) (7-36) amide in type 2 diabetic patients. J Clin Endocrinol Metab 81:327-332.

Wolgin DL, Wade JV (1990) Effect of lithium chloride-induced aversion on appetitive and consummatory behavior. Behav Neurosci 104:438-440.

Woods SC, Seeley RJ, Porte DJ, Schwartz MW (1998) Signals that regulate food intake and energy homeostasis. Science 280:1378-1383. 